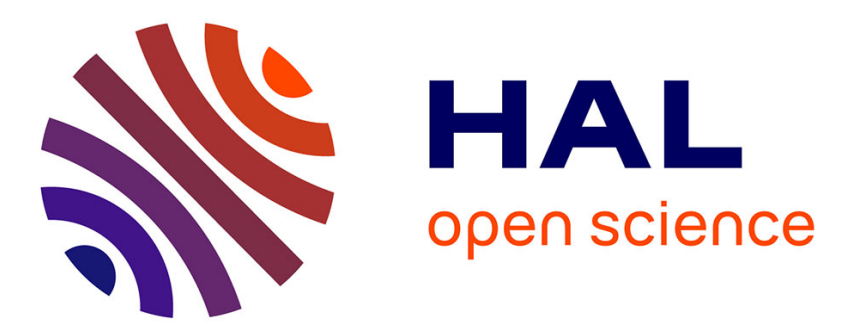

\title{
Mitochondrial DNA of Euglossa iopoecila (Apidae, Euglossini) reveals two distinct lineages for this orchid bee species endemic to the Atlantic Forest
}

Rafael E. S. Penha, Maria C. Gaglianone, Fernanda S. Almeida, Samuel V. Boff, Silvia H. Sofia

\section{To cite this version:}

Rafael E. S. Penha, Maria C. Gaglianone, Fernanda S. Almeida, Samuel V. Boff, Silvia H. Sofia. Mitochondrial DNA of Euglossa iopoecila (Apidae, Euglossini) reveals two distinct lineages for this orchid bee species endemic to the Atlantic Forest. Apidologie, 2015, 46 (3), pp.346-358. 10.1007/s13592014-0329-7 . hal-01284450

\section{HAL Id: hal-01284450 \\ https://hal.science/hal-01284450}

Submitted on 7 Mar 2016

HAL is a multi-disciplinary open access archive for the deposit and dissemination of scientific research documents, whether they are published or not. The documents may come from teaching and research institutions in France or abroad, or from public or private research centers.
L'archive ouverte pluridisciplinaire HAL, est destinée au dépôt et à la diffusion de documents scientifiques de niveau recherche, publiés ou non, émanant des établissements d'enseignement et de recherche français ou étrangers, des laboratoires publics ou privés. 


\title{
Mitochondrial DNA of Euglossa iopoecila (Apidae, Euglossini) reveals two distinct lineages for this orchid bee species endemic to the Atlantic Forest
}

\author{
Rafael E. S. Penha ${ }^{1,2}$, Maria C. Gaglianone ${ }^{3}$, Fernanda S. Almeida ${ }^{1}$, Samuel V. Boff ${ }^{4}$, \\ Silvia H. SOFIA ${ }^{1}$ \\ ${ }^{1}$ Laboratório de Genética e Ecologia Animal, Departamento de Biologia Geral, Universidade Estadual de Londrina, \\ Rodovia Celso Garcia Cid, km 380, 86051-970, Londrina, PR, Brazil \\ ${ }^{2}$ Programa de Pós-Graduação em Genética e Biologia Molecular, Universidade Estadual de Londrina, Rodovia Celso \\ Garcia Cid, km 380, 86051-970, Londrina, PR, Brazil \\ ${ }^{3}$ Laboratório de Ciências Ambientais, Programa de Pós-Graduação em Ecologia e Recursos Naturais, Universidade \\ Estadual do Norte Fluminense Darcy Ribeiro, Av. Alberto Lamego, 2000, Parque Califórnia, 28013-602, Campos dos \\ Goytacazes, RJ, Brazil \\ ${ }^{4}$ General Zoology, Martin-Luther-Universität Halle-Wittenberg, Hoherweg 8, 06108, Halle, Saale, Germany
}

Received 13 May 2014 - Revised 16 September 2014 - Accepted 8 October 2014

\begin{abstract}
This study analysed the population genetic structure of Euglossa iopoecila, an orchid bee species endemic to the Atlantic Forest which shows a variation in the colour of its metallic integument across its distribution. Our analyses were based on microsatellite and mitochondrial markers. From ten microsatellite loci surveyed, six are described herein for the first time. Mitochondrial markers were obtained by sequencing $651 \mathrm{bp}$ of $C y t b$ gene. Bees were collected from six Atlantic Forest remnants distributed along the Serra do Mar Biodiversity Corridor, which is one of the largest remnants of dense forest within the Atlantic Forest of southern and south-eastern Brazil. The microsatellite markers showed lower levels of genetic structure than those found for mitochondrial markers. Our findings based on mitochondrial markers indicate the existence of at least two different evolutionarily significant units of E. iopoecila populations along the Serra do Mar Biodiversity Corridor.
\end{abstract}

euglossine / genetic diversity / microsatellite markers / mtDNA / evolutionarily significant units

\section{INTRODUCTION}

A number of recent reports in the literature have indicated declines in bee populations across the world, an issue that has become a serious concern for the scientific community (Brown and Paxton 2009; Freitas et al. 2009). Various anthropogenic causes have been attributed to this decline (Brown

Electronic supplementary material The online version of this article (doi:10.1007/s13592-014-0329-7) contains supplementary material, which is available to authorized users.

Corresponding author: S. Sofia, shsofia@uel.brH. Sofia,shsofia@uel.br

Manuscript editor: Klaus Hartfelder and Paxton 2009). However, the destruction of tropical forest worldwide (Bawa and Seidler 1998) is certainly among the most important (Freitas et al. 2009). In this scenario, the main genetic threat to bees comes from the loss of genetic diversity associated with declines in population sizes, a picture that can be severely aggravated when gene flow is limited or disrupted, leading to the potential extinction of local populations (Frankham et al. 2010).

In the Neotropics, several species of Euglossini bees, also known as orchid bees, have been the focus of genetic studies over the last decade, since it has been suggested by different authors that some species of this group of bees could be adversely affected by deforestation and habitat fragmentation (Giangarelli et al. 2009; Nemésio 
2011). Actually, the latter author reports what may be the first documented local extinction for an orchid bee species, endemic to Atlantic Forest (AF) and dependent on forest areas. However, contrary to what would be expected of bees considered sensitive to habitat disturbance, most population genetic studies on euglossine bees have shown that the majority of the species investigated exhibit high levels of genetic diversity and, at most, modest genetic structuring (Zimmermann et al. 2011; Rocha-Filho et al. 2013; Boff et al. 2014; Suni et al. 2014). In all these studies, genetic analyses were based mainly on nuclear markers. However, when López-Uribe et al. (2014) analysed the genetic diversity and population structure of three orchid bee species (Eulaema bombiformis, Eulaema meriana and Eulaema cingulata) using both nuclear and mitochondrial markers, they detected discrepant results between the two types of markers regarding the structuring of populations of these species.

For conservation purposes, knowing the degree of genetic structure within a population is essential for making decisions on measures aimed at managing populations subjected to anthropogenic threats (Frankham et al. 2010). Thus, based on the recent findings of López-Uribe et al. (2014), it seems logical to use a combination of nuclear and mitochondrial markers to achieve a better understanding of the genetic structure of Euglossini populations.

In the South America, approximately 50 species of the Euglossini tribe occur in areas of the $\mathrm{AF}$ and half of this total is considered endemic to this threatened Neotropical forest (Nemésio 2009). Among these species, Euglossa iopoecila Dressler is a bee that is almost exclusive to the rainforest (RF) areas along the Brazilian AF coastline (Faria Jr. and Melo 2007; Nemésio 2009).

According to Faria Jr. and Melo (2007), E. iopoecila populations show variations in integument colour across their distribution range. The colour varies from blue-violet in the southern regions of the species' distribution in this area of AF (Brazilian states of Santa Catarina and Paraná) to green in the more northerly regions (Espírito Santo and Bahia). In addition, this variation in integument colour appears to be gradual, with intermediate shades between blue-violet and green being found in populations occurring in intermediate areas of the distribution limits (Faria Jr. and Melo 2007). Recently, based on genetic analyses, Ferrari and Melo (2014) found that the differences in integument colour exhibited by E. iopoecila individuals along the AF coastline do not support the occurrence of two distinctive species, as has been suggested (Nemésio 2009).

In discussions of the phenotypic variation and endemism of E. iopoecila in areas of RF, this bee becomes of particular interest for population studies involving the Euglossini tribe. In the case of E. iopoecila, the phenotypic differences exhibited by populations may also be associated with genetic differences within populations. In recent decades, conservation genetics has highlighted the importance of studies that enable us to determine whether these populations represent distinct evolutionarily significant units (ESU). ESUs have been defined as historically isolated and independently evolving sets of populations (Moritz 1999), which should therefore be given priority for conservation purposes and managed separately (Frankham et al. 2010). However, before ESUs are identified, it is necessary to develop population genetic studies that will provide information on the genetic structure and diversity of the different populations. In the specific case of E. iopoecila, very little is known of the population genetic structure of this euglossine bee.

Several characteristics of the mitochondrial genome, including its uniparental maternal inheritance (Avise 2004), combined with the acknowledged philopatry of orchid bee females (Augusto and Garófalo 2004; Cerântola et al. 2011; RochaFilho et al. 2013) and the limitations in the sampling of these females, mean that mitochondrial markers are appropriate tools for population genetic studies on euglossine bees. The concomitant use of microsatellite markers, which characteristically evolve quickly, are highly variable and widely distributed in the nuclear genome (Avise 2004) and could undoubtedly complement the information provided by mitochondrial markers (mtDNA). Furthermore, the combined use of microsatellite and mtDNA markers for population studies can help us better understand the distribution of genetic variation across different spatial and temporal scales, since microsatellite markers 
are informative for recent or ongoing microevolutionary processes, whereas mtDNA markers are more suitable for historical processes (Wang 2010).

Populations of E. iopoecila are distributed throughout the Serra do Mar Biodiversity Corridor (SMBC), which is one of the largest remnants of $\mathrm{RF}$ and is considered to be an area with high biodiversity (Galindo-Leal and Câmara 2003). Located along the eastern Brazilian coast, the SMBC spans three states in southern and south-eastern Brazil (Paraná, São Paulo and Rio de Janeiro). Along the SMBC, E. iopoecila exhibits its main phenotypic variation, showing blue integument in the south and individuals with green integument in the north of the SMBC (Faria Jr. and Melo 2007).

In this study, we investigated the genetic diversity and structure of E. iopoecila populations along the SMBC using both mtDNA and microsatellite markers.

\section{MATERIALS AND METHODS}

\subsection{Study areas}

Males of E. iopoecila (Figure 1) were collected in six Atlantic Forest remnants of RF vegetation in the states of Paraná (PR), São Paulo (SP) and Rio de Janeiro (RJ) (Table IS, Figure 2). Additional information on the study sites can be found in Ramalho et al. (2009), Rocha-Filho et al. (2013) and Boff et al. (2014).

\subsection{Bee sampling}

Bees were collected along $707 \mathrm{~km}$ of the SMBC (Figure 2) from April 2009 to May 2010 (at Salto Morato Reserve (SM)); from November 2011 to January 2013 (Superagui Island=SI) and during March 2012 in São Sebastião (SS), on Ilhabela Island (IB), in Ubatuba (UB) and in the União Reserve (UR). The methods for sampling euglossine males followed Giangarelli et al. (2009) and Ramalho et al. (2009). Voucher specimens have been deposited in the Zoological Museum of Londrina State University.

\subsection{DNA extraction and genetic analyses}

DNA was extracted from the left hind leg of bees following the protocol of Freiria et al. (2012).

\subsubsection{Microsatellite markers}

Of the 14 tested heterologous primers described for Euglossa annectans (Paxton et al. 2009) and Euglossa cordata (Souza et al. 2007), only four (ann24, ann37, Egc18 and Egc26) efficiently amplified the microsatellite loci and/or were shown to be polymorphic. Thus, a further six microsatellite primers specific to E. iopoecila were generated and used in this study to provide a total of ten primers.

The construction of these six new primers was based on a microsatellite-enriched library following the protocol described by Billotte et al. (1999), with minor modifications. A total of 80 recombinant clones were sequenced by Macrogen (South Korea). The sequences obtained were analysed using BioEdit v.7.0 (Hall 1999) and primers designed using Primer 3 (Rozen and Skaletsky 2000). Autodimer software (Vallone and Butler 2004) was used to identify potential hairpin structures and dimerization issues among the primers.

The primers were initially tested on 48 E. iopoecila males, representing samples from the six populations: Salto Morato Reserve $(\mathrm{SM})=8$ and Superagui Island $(\mathrm{SI})=5$, both in the state of Paraná, southern Brazil; São Sebastião=9 (SS), 10 Ilhabelha Island $(\mathrm{IB})=10$ and Ubatuba (UB) $=8$ in the state of São Paulo, southeastern Brazil and União Reserve (UR) $=8$, in the state of Rio de Janeiro, also in southeastern Brazil (Figure 2). Analysing a higher number of individuals than is usual in testing new microsatellite primers was an attempt to minimise possible deviations in the population analysis, since females were not available for analysis. From the total group of primers, six were selected for population analyses in this study.

For genotyping, the forward primer for each locus was labelled with a M13 fluorescent-sequence (5'TGTAAAACGACGGCCAGT-3') at the $5^{\prime}$ end (Schuelke 2000). Polymerase chain reactions (PCRs) were set up in $5-\mu \mathrm{L}$ reaction volumes comprising $2.5 \mu \mathrm{L}$ GoTaq Master Mix 2x (Promega), $0.5 \mu \mathrm{M}$ of tag-F primer $+5 \mu \mathrm{M}$ R-primer mixture, $5 \mu \mathrm{M}$ M13 primer, $50 \%$ glycerol $(0.1 \mu \mathrm{L}), 5 \mathrm{ng}$ template DNA and $1.15 \mu \mathrm{L}$ nuclease-free water (Promega). Samples were amplified in a thermocycler (PCT-100 Peltier Thermal Cycler MJ), as follows $-94{ }^{\circ} \mathrm{C}$ for $4 \mathrm{~min}$, followed by 10 cycles of $94{ }^{\circ} \mathrm{C} / 30 \mathrm{~s}, 56$ and $72{ }^{\circ} \mathrm{C} /$ $1 \mathrm{~min}$, followed by 25 cycles of $89{ }^{\circ} \mathrm{C} / 30 \mathrm{~s}, 56{ }^{\circ} \mathrm{C} /$ $1 \mathrm{~min}, 72{ }^{\circ} \mathrm{C} / 1 \mathrm{~min}$ and a final extension at $72{ }^{\circ} \mathrm{C} /$ $30 \mathrm{~min}$. 
a

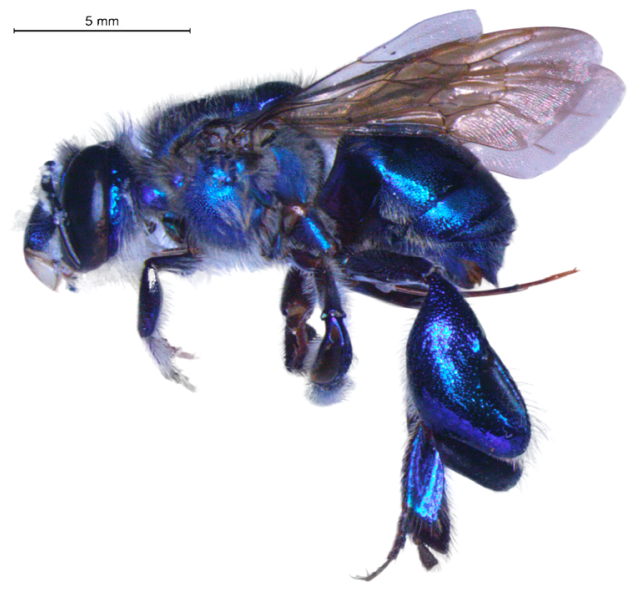

b

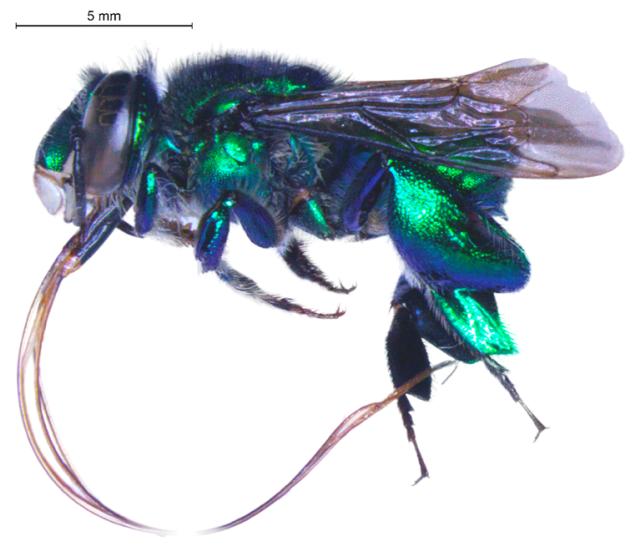

Figure 1. Males of E. iopoecila collected at: a Salto Morato Natural Reserve (SM, Reserva Natural Salto Morato ), State of Paraná, exhibiting blue colour; b União Reserve (UR), State of Rio de Janeiro, exhibiting green colour.

PCR products were then resolved in an ABI PRISM 3500-XL automated sequencer (Applied Biosystems) using GeneScan 600 Liz (Applied Biosystems) as a molecular weight marker. The genotypes were read using GeneMarker v.2.2.0 (SoftGenetics) based on manual checking.

\subsection{2. $m t D N A$ markers}

A segment of approximately $651 \mathrm{bp}$ of the mitochondrial Cytb gene was amplified using CB-J-10612 and CB-N-11367 primers (Simon et al. 1994). PCRs were performed as follows-10 ng DNA, 1x buffer, $3 \mathrm{mM} \mathrm{MgCl}_{2}, 0.5 \mu \mathrm{M}$ each primer, $200 \mu \mathrm{M}$ dNTPs and $1 \mathrm{U}$ of Taq DNA polymerase (Invitrogen) in a final reaction volume of $20 \mu \mathrm{L}$. Amplifications were performed in a thermocycler (PCT-100 Peltier Thermal Cycler) as follows-initial denaturation at $94{ }^{\circ} \mathrm{C} /$ $5 \mathrm{~min}$, followed by 35 cycles (denaturation at $94{ }^{\circ} \mathrm{C} /$ $60 \mathrm{~s}$, annealing at $48{ }^{\circ} \mathrm{C} / 80 \mathrm{~s}$, and extension at $72{ }^{\circ} \mathrm{C}$ ) and a final extension at $72{ }^{\circ} \mathrm{C} / 10 \mathrm{~min}$.

The PCR products were subsequently purified with Illustra Exostar kit (GE Healthcare), following the manufacturer's protocol, and subjected to a sequencing reaction using the BigDye Terminator v3.1 (Applied Biosystems) kit. PCR products were then sequenced in ABI PRISM 3500-XL. The presence of linkage disequilibrium among pairs of loci was tested by GENEPOP 4.2 (Raymond and Rousset 1995; Rousset 2008); $p$ values were subsequently adjusted using the sequential Bonferroni correction.

\subsection{Data analysis}

\subsubsection{Microsatellites}

The genotyping data generated by the automated sequencer were visualised and analysed using GeneMarker v.2.2.0.

Measures of the genetic diversity were calculated as follows: (a) allelic richness $(A R)$, mean allele number for all loci in each population $\left(\bar{N}_{A}\right)$ and the effective number of alleles $\left(\bar{N}_{E}\right)$ in GenAlEx 6.5 (Peakall and Smouse 2012); (b) mean expected heterozygosity $\left(\bar{H}_{e}\right)$ calculated by Arlequin 3.5.1.3 (Excoffier and Lischer 2010). Also, taking into consideration that allelic richness depends on sample size, we used HP-RARE (Kalinowski $2005)$ to estimate allelic and private allelic richness at all populations of E. iopoecila surveyed in our study. To compare the levels of genetic diversity among the six populations, the $H_{e}$-values from ten microsatellite loci amplified in each population were submitted to arcsine-transformation (Archie 1985) and the mean $H_{e}$ obtained then compared using one-way ANOVA.

Population genetic structure was surveyed to calculate: (a) $F_{\mathrm{ST}}$-values provided by analysis of molecular 


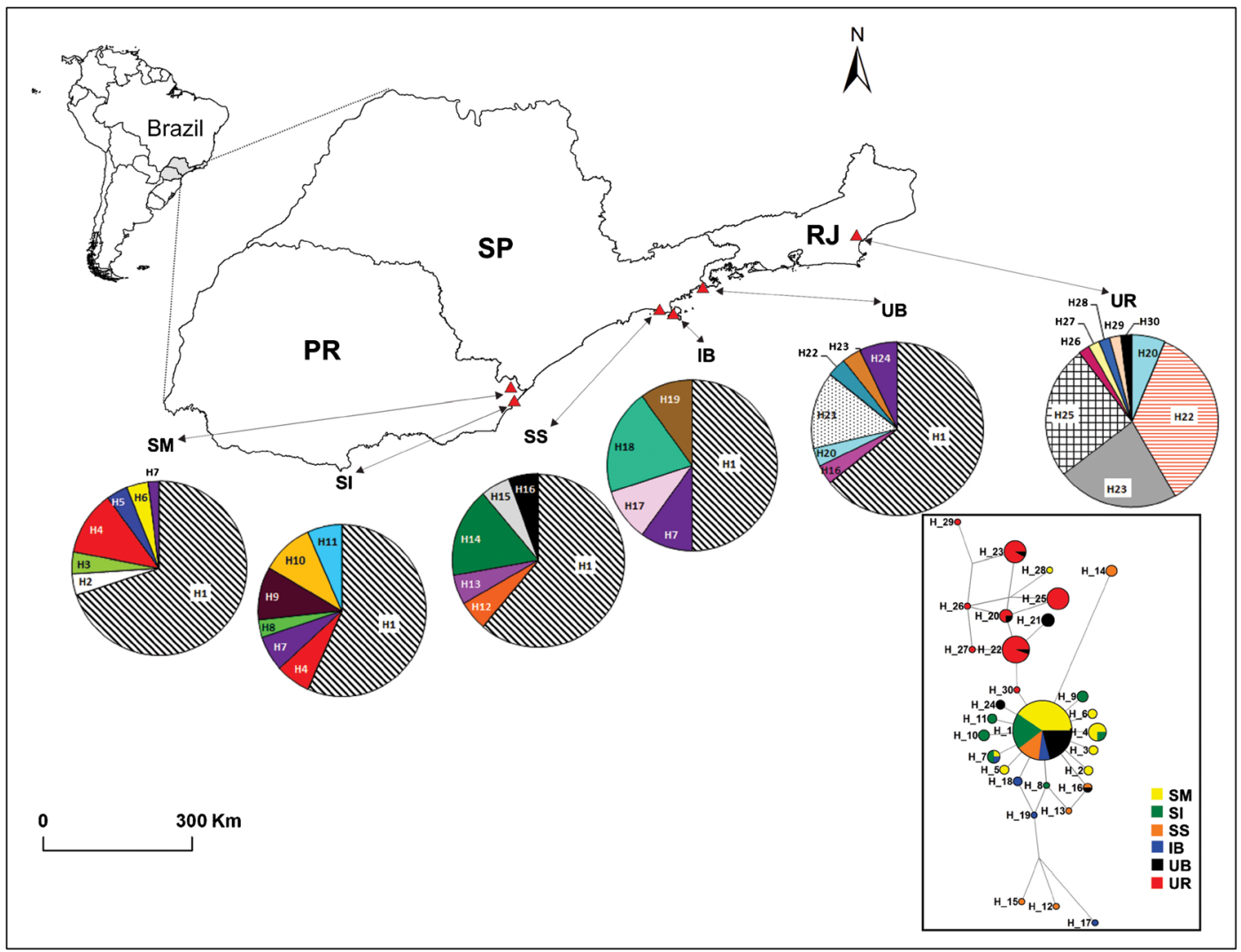

Figure 2. Map of South America, showing the study area (dotted) including the sampling sites in the states of Paraná (PR), São Paulo (SP) and Rio de Janeiro (RJ). $S M=$ Salto Morato Natural Reserve; $I S=$ Superagui Island; $S S=$ São Sebastião; $I B=$ =Ilhabela Island; $U B=$ Ubatuba; $U R=$ União Reserve. (Software ArcGIS 10.2). On the right side below is shown the haplotype network generated using Network 4.6.1 software, based on the medianjoining method. Circle sizes are proportional to haplotype (H)frequency. Different haplotypes are represented by numbers ranging from 1 to 30 .

variance (AMOVA) (Excoffier et al. 1992), using Arlequin 3.5.1.3; (b) $D_{\text {est }}$ estimates (Jost 2008) using GenAlEx 6.5. For both estimators, significance was obtained after 1,000 randomisations. In all analyses performed, only the $p$ values $<0.05$ were considered significant.

\subsection{2. $m t D N A$}

The sequences were visualised, edited and aligned in Bioedit v.7.1.7. Contigs were designed using the DNA Baser Sequence Assembler v3.x (http://www.DnaBaser.com). DnaSP v.5 (Librado and Rozas 2009) was then used to generate data for Arlequin 3.5.1.3 and NETWORK v.4.6 (www.fluxus-engineering.com). NETWORK v.4.6 was used to construct a haplotype network based on the median-joining method (Bandelt et al. 1999) and Arlequin 3.5.1.3 to calculate haplotype and nucleotide diversity and to obtain the ${ }_{\mathrm{mt}} F_{\mathrm{ST}}$-values using AMOVA. The number of haplotypes, haplotype diversity $(h)$ and nucleotide diversity $(\pi)$ corresponded to measurements of genetic diversity. For the mtDNA data, we also performed a Bayesian analysis to investigate the genetic differentiation between populations. This analysis was carried out using BAPS ver. 6.0 (Corander et al. 2008). We estimated $K$ (groups of individuals with known locations in clusters) using individuals with an admixture analysis based on mixture clustering of individuals. To estimate admixture coefficients among clusters, we ran 1,000 interactions using 2,000 reference individuals from each population and ten interactions to calculate the admixture coefficients for the reference individuals. 
To test for correlations between genetic and geographic distances, we ran the Mantel test on GENEPOP ver. 4.2 (Raymond and Rousset 1995; Rousset 2008), with 10,000 randomizations. This analysis was performed individually for the three genetic differentiation measurements ( ${ }_{\mathrm{mt}} F_{\mathrm{ST}}, F_{\mathrm{ST}}$ and/or $\left.D_{\text {est }}\right)$.

\section{RESULTS}

\subsection{New microsatellite primers}

From the genomic microsatellite-enriched library constructed for E. iopoecila, a total of 23 primer pairs were designed and tested. Of these, six were tested and amplified successfully across a large number of E. iopoecila males, and thus, only these primer pairs are presented herein. The other ten pairs did not amplify sufficiently to be used in this study. The sequences of these six microsatellite primers, as well as the number of alleles found for each of these primers and variation in allele size, are shown in Table I. The number of alleles found per locus varied from four (iop16) to 33 (iop3), averaging 15.33, and the size of the amplified alleles ranged from 161 to 287 bp. All six primers were polymorphic and apparently well-suited to the study of the genetic diversity and structure of E. iopoecila populations. These six primers were subsequently amplified in 302 males of E. iopoecila from the six study populations. No hairpin structures or null alleles were detected for any locus. Tests for linkage disequilibrium between loci equilibrium were all non-significant $(p>0.05)$ after Bonferroni correction.

\subsection{Genetic diversity}

The amplification of the ten microsatellite loci revealed 138 distinct alleles, made up of 94 shared by two or more individuals and 44 unique alleles.

The highest estimated mean number of allelic richness $\left(\bar{N}_{A}=8.8\right)$ and the highest mean number of effective alleles $\left(\bar{N}_{E}=4.9\right)$ were observed in the sample from the São Sebastião (SS) remnant. In contrast, the population from Superagui Island (southern Brazil) exhibited the lowest values for $\bar{N}_{A}$ (4.6) and $\bar{N}_{E}(0.61) ; \bar{H} e$-values ranged from 0.58 (Superagui Island) to 0.72 (São Sebastião). In addition, the private allelic richness found varied from 0.10 (Ubatuba in São Paulo State) to 1.25 (União Reserve in Rio de Janeiro State) (Table II).

There were problems in amplifying and/or sequencing samples of several individuals from different areas in the mitochondrial analysis, resulting in low-quality products that were therefore discarded. Thus, a total of 184 males were included in the mtDNA analysis (Table II). For

Table I. The sequences of six microsatellite loci, together with the associated number of alleles (Na) and the sizes of the alleles in base pairs and observed for the 302 samples from males of E. iopoecila analysed and GenBank accession numbers for each marker.

\begin{tabular}{lllccc}
\hline Locus & Sequence repeat & Primers sequences $\left(5^{\prime}-3^{\prime}\right)$ & Na & $\begin{array}{c}\text { Allele size } \\
\text { range }(\mathrm{pb})\end{array}$ & $\begin{array}{l}\text { GenBank accession } \\
\text { numbers }\end{array}$ \\
\hline iop1 & $(\mathrm{TC})_{23}$ & $\begin{array}{l}\text { F: TCTCCCGTAAAATGCTCTCG } \\
\text { R: CCCGGTAGACGTTTGCTCG }\end{array}$ & 21 & $195-248$ & KJ663706 \\
iop2 & $(\mathrm{TC})_{14}$ & $\begin{array}{l}\text { F: CGTCTCCTTTCACCACCTTC } \\
\text { R: GGAAGAAGAGACGCACAAGG }\end{array}$ & 7 & $195-212$ & KJ663707 \\
iop3 & $(\mathrm{CT})_{15}$ & $\begin{array}{l}\text { F: CGCGAACATTGGAACGAATC } \\
\text { R: CGCAGGCTCTTAGGAGGTAA }\end{array}$ & 33 & $228-287$ & KJ663708 \\
iop4 & $(\mathrm{TC})_{19}$ & $\begin{array}{l}\text { F: AGAATAAGCCGACGGAAACC } \\
\text { R: AGCTGTGTTCCGCTTTGAC }\end{array}$ & 17 & $207-258$ & KJ663709 \\
iop13 & $(\mathrm{AG})_{11}$ & $\begin{array}{l}\text { F: ACGGGACAACCCCGTATAAT } \\
\text { R: AGGGATTTCCTCTCCTCTCG }\end{array}$ & 10 & $161-180$ & KJ663710 \\
iop16 & $(\mathrm{CTT})_{7} \mathrm{CTC}$ & $\begin{array}{l}\text { F: CCACGACTTAACGAGCCTTC } \\
\text { R: GTGAAGGAGTGGGACCTCTG }\end{array}$ & 4 & $203-212$ & KJ663711 \\
& $(\mathrm{CTT})_{5}$ & & & \\
\hline
\end{tabular}


Table II. Genetic diversity of E. iopoecila at six study areas of the Atlantic rainforest, estimated based on microsatellite (nuDNA) and mtDNA (Cytb) markers.

\begin{tabular}{|c|c|c|c|c|c|c|c|c|c|c|}
\hline \multirow[t]{2}{*}{ Populations } & \multicolumn{6}{|c|}{ Microsatellites (nuDNA) } & \multicolumn{4}{|c|}{ mtDNA } \\
\hline & $N$ & $A R$ & $P A$ & $\bar{N}_{A}$ & $\bar{N}_{E}$ & $\bar{H} e$ & $N$ & $N h$ & $h$ & $\pi$ \\
\hline SM & 60 & 5.71 & 0.54 & 6.3 & 0.97 & 0.65 & 50 & 7 & 0.499 & 0.0087 \\
\hline SI & 31 & 4.54 & 0.41 & 4.6 & 0.61 & 0.58 & 30 & 7 & 0.667 & 0.0013 \\
\hline SS & 57 & 7.58 & 0.91 & 8.8 & 1.05 & 0.72 & 18 & 6 & 0.621 & 0.0036 \\
\hline IB & 57 & 7.33 & 0.74 & 8.6 & 1.05 & 0.70 & 10 & 5 & 0.756 & 0.0026 \\
\hline UB & 37 & 6.27 & 0.10 & 6.5 & 1.02 & 0.66 & 28 & 7 & 0.577 & 0.0022 \\
\hline UR & 60 & 7.09 & 1.25 & 8.1 & 1.03 & 0.68 & 48 & 9 & 0.770 & 0.0024 \\
\hline
\end{tabular}

$A R$ allelic richness, $P A$ private allelic richness, $\bar{N}_{A}$ mean allele number for all loci in each population, $\bar{N}_{E}$ mean effective number of alleles for all loci in each population, $\bar{H} e$ mean expected heterozygosity, $N h$ number of haplotypes found, $h$ haplotype diversity, $\pi$ nucleotide diversity, $S M$ Salto Morato Reserve, SI Superagui Island, SS São Sebastião, IB Ilhabela Island, $U B$ Ubatuba, $U R$ (União Reserve), $N$ number of individuals analysed

these males, a 651-bp sequence of the $C y t b$ gene was analysed, which exhibited 25 variable sites and 30 different haplotypes (Figure 2; Table IS). The overall values found for haplotype $(h)$ and nucleotide $(\pi)$ diversity were 0.762 and 0.0033 , respectively.

The number of haplotypes found ranged from five (Ilhabela Island) to nine (União Reserve), while haplotype diversity $(h)$ ranged from 0.499 (Salto Morato) to 0.77 (União Reserve), and nucleotide diversity from 0.0022 (Ilhabela) to 0.0087 (Salto Morato Reserve) (Table II).

Among the haplotypes identified, H1 was the most common. It was present in 86 of the 184 individuals analysed at a frequency of occurrence ranging locally from $50 \%$ (Ilhabela) to $70 \%$ (Salto Morato Reserve). In contrast, this haplotype was not present in União Reserve (Rio de Janeiro state). This was the only location at which the individuals exhibited green integument. The União Reserve sample shared haplotypes only with Ubatuba (H20, H22 and H23 in particular), and Ubatuba was the only population that shared haplotypes with all the other populations analysed (Figure 2; Table IIS).

\subsection{Genetic structure}

For the six populations analysed, the AMOVA performed based on microsatellite markers revealed that the majority $(93.2 \%)$ of the genetic variation is distributed within populations. The estimated global genetic differentiation $\left(F_{\mathrm{ST}}\right)$ was $0.068(p<0.00001)$, whereas the estimated global $D_{\text {est }}$ value was $0.109(p<0.001)$, both indicating a moderate genetic structure in the populations sampled. Comparisons between pairs of populations for the $D$ est and $F_{\text {ST }}$ estimators showed that the highest values occurred between the samples from the União Reserve (UR) and Ilhabela regions (Table III).

For mtDNA analysis, AMOVA revealed that approximately half the genetic variation is distributed within populations (51.17\%), and $48.83 \%$ is distributed among populations. The global ${ }_{\mathrm{mt}} F_{\mathrm{ST}}$ value calculated was 0.49 , which was highly significant $(p<0.0001)$.

Except for the São Sebastião (SS)-Ilhabela Island (IB) (both in São Paulo state) and Salto Morato-Superagui Island (both in Paraná state) comparisons, all other pairs of populations showed significant values of ${ }_{\mathrm{mt}} F_{\mathrm{ST}}(p<0.0001)$ (Table III).

The haplotype network generated showed that 19 haplotypes were unique (Figure 2). Of the 30 haplotypes identified, four (13.33\%) occurred at frequencies above $5 \%$, with the frequency of occurrence usually varying between different samples. Within the Salto Morato population, individuals showed a difference of only $1 \mathrm{bp}$ between haplotypes, while within the União Reserve population there was variation of up to $9 \mathrm{bp}$ (Figure 2).

BAPS analysis showed a population structure formed by two genetic units (mtDNA lineages) or 
$K=2$, as follows: Unit $1=$ clustering bees from Salto Morato, Superagui Island, São Sebastião and Ilhabela Island; unit $2=$ except for one individual, this unit clustered all individuals from União Reserve (Rio de Janeiro State). Finally, the Ubatuba population clustered individuals of both units, appearing as a mixture of units 1 and 2 .

We found a significant positive correlation between the logarithm of geographical distance $(\mathrm{km})$ and the genetic distances $\left[\left(F_{\mathrm{ST}} /\left(1-F_{\mathrm{ST}}\right)\right]\right.$ based on both nuclear $\left(F_{\mathrm{ST}}, r=0.67 ; p<0.005 ; D_{\text {est }}\right.$, $r=0.71 ; p<0.05$; Figure $3 \mathrm{a}, \mathrm{b})$ and mtDNA markers ( ${ }_{\mathrm{mt}} F_{\mathrm{ST}}, r=0.58 ; P<0.01$; Figure $3 \mathrm{c}$ ), indicating an isolation-by-distance effect among the populations.

\section{DISCUSSION}

Our results show conspicuous differences between $F_{\text {ST }}$-values found when mitochondrial and microsatellite markers were used to analyse the genetic structure of the six populations of E. iopoecila surveyed in our study. Overall, the hierarchical $F$-statistics results obtained using mitochondrial markers were higher than those obtained with microsatellite markers. In fact, whereas the global values of both $F_{\mathrm{ST}}$ and $D_{\text {est }}$ derived from the microsatellite data set were 0.068 and 0.106 , respectively, the global ${ }_{\mathrm{mt}} F_{\mathrm{ST}}$ was 0.49 . Taking into consideration the theoretical scale of $F_{\text {ST }}$ values, usually used to measure the degree of genetic differentiation between populations (Wright 1978), the global estimate of $F_{\text {ST }}$ (and $D_{\text {est }}$ ) revealed by microsatellite markers indicates a modest level of genetic differentiation across most of the populations surveyed. Specifically, according to Wright (1978), theoretical values of $F_{\mathrm{ST}}$ ranging from 0.05 to 0.15 are indicative of moderate genetic differentiation between pairs of populations. On the other hand, the global ${ }_{\mathrm{mt}} F_{\mathrm{ST}^{-}}$

Table III. Geographic distance (kilometers) between the study areas and pairwise genetic differentiation as $F_{\mathrm{ST}}$ and $D_{\text {est }}$ E. iopoecila populations surveyed at six Atlantic Forest remnants (SM=Salto Morato Reserve; SS=São Sebastião; SI=Superagui Island; IB=Ilhabela Island; UB=Ubatuba, and UR=União Reserve, see also Figure 2), estimated from the two molecular markers used.

\begin{tabular}{lclll}
\hline Pairs of populations & Geographic distance $(\mathrm{km})$ & \multicolumn{2}{l}{ Microsatellites } & \multirow{2}{*}{ mtDNA } \\
\cline { 3 - 5 } & & $\mathrm{F}_{\mathrm{ST}}$ & $\mathrm{D}_{\text {est }}$ & ${ }_{\mathrm{mt}} \mathrm{F}_{\mathrm{ST}}$ \\
\hline $\mathrm{SM} \times \mathrm{SI}$ & 28 & $0.03^{* * *}$ & $0.05^{* *}$ & $0.02^{*}$ \\
$\mathrm{SM} \times \mathrm{SS}$ & 313 & $0.03^{* * *}$ & $0.11^{* *}$ & $0.14^{* * *}$ \\
$\mathrm{SM} \times \mathrm{IB}$ & 332 & $0.04^{* * *}$ & $0.15^{* *}$ & $0.22^{* * *}$ \\
$\mathrm{SM} \times \mathrm{UB}$ & 405 & $0.04^{* * *}$ & $0.11^{* *}$ & $0.15^{* * *}$ \\
$\mathrm{SM} \times \mathrm{UR}$ & 707 & $0.05^{* * *}$ & $0.15^{* *}$ & $0.70^{* * *}$ \\
$\mathrm{SI} \times \mathrm{SS}$ & 324 & $0.05^{* * *}$ & $0.14^{* *}$ & $0.09^{* * *}$ \\
$\mathrm{SI} \times \mathrm{IB}$ & 341 & $0.05^{* * *}$ & $0.16^{* *}$ & $0.14^{* * *}$ \\
$\mathrm{SI} \times \mathrm{UB}$ & 415 & $0.04^{* * *}$ & $0.10^{* *}$ & $0.12^{* * *}$ \\
$\mathrm{SI} \times \mathrm{UR}$ & 714 & $0.05^{* * *}$ & $0.14^{* *}$ & $0.66^{* * *}$ \\
$\mathrm{SS} \times \mathrm{IB}$ & 30 & $0.02^{* * *}$ & $0.06^{* *}$ & $0.001^{\mathrm{n} . \mathrm{s}}$ \\
$\mathrm{SS} \times \mathrm{UB}$ & 68 & $0.02^{* * *}$ & $0.06^{*}$ & $0.12^{* * *}$ \\
$\mathrm{SS} \times \mathrm{UR}$ & 395 & $0.03^{* * *}$ & $0.10^{* *}$ & $0.59^{* * *}$ \\
$\mathrm{IB} \times \mathrm{UB}$ & 76 & $0.03^{* * *}$ & $0.01^{* *}$ & $0.16^{*}$ \\
$\mathrm{IB} \times \mathrm{UR}$ & 375 & $0.05^{* * *}$ & $0.18^{* *}$ & $0.62^{* * *}$ \\
$\mathrm{UB} \times \mathrm{UR}$ & 305 & $0.02^{* * *}$ & $0.05^{* *}$ & $0.49^{* * *}$ \\
\hline
\end{tabular}

n.s. nonsignificant

${ }^{*} p<0.05,{ }^{* *} p<0.005,{ }^{* * *} p<0.00001$ levels of significance 
Figure 3. Relationship between the logarithm of geographical distance (kilometers) and genetic distances $\left[\left(F_{\mathrm{ST}} /\right.\right.$ $\left.\left.\left.1-F_{\mathrm{ST}}\right)\right)\right]$ estimated for different pairs of the E. iopoecila populations. Microsatellite markers: a Geographical distance $\times F_{\mathrm{ST}}$, b Geographical distance $\times D_{\text {est }}$. Mitochondrial marker: c Geographic distance $\times{ }_{\mathrm{mt}} F_{\mathrm{ST}}$.
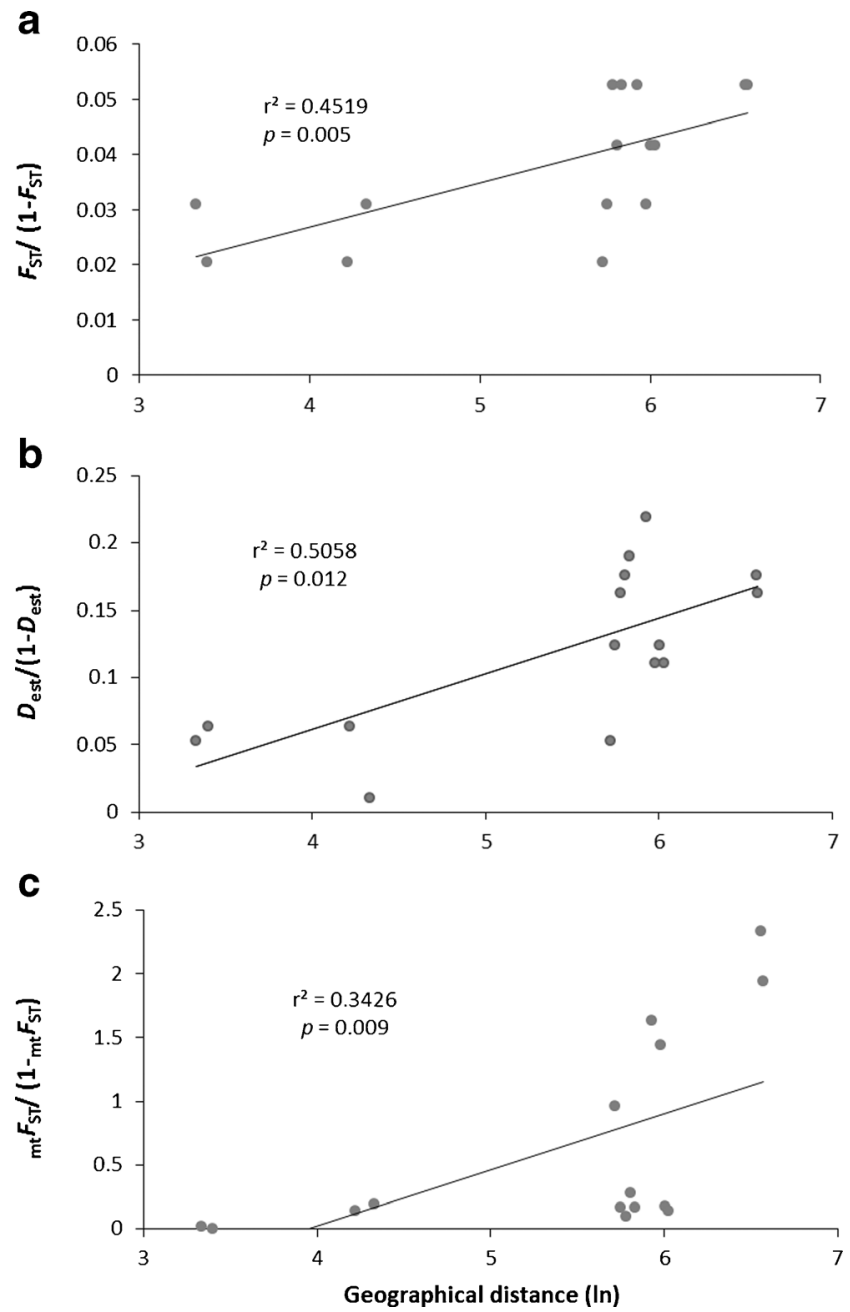

value, in accordance with Wright's arbitrary scale, indicates a high degree of genetic differentiation across E. iopoecila populations.

The incongruence between the patterns of genetic structure found for the nuclear (nuDNA) and mitochondrial (mtDNA) markers corroborates the recent findings of López-Uribe et al. (2014), who also used both mtDNA and nuDNA data sets and detected a conspicuously higher genetic structure in populations of three euglossine species revealed by mtDNA. These authors proposed several possible causes for the discrepant cyto-nuclear patterns found for the three orchid bee species studied, including a longterm male-biased dispersal resulting in panmixia in the nuDNA and genetic structure in the mtDNA. Indeed, different authors have already pointed out males as the disperser sex in euglossine bees (Cerântola et al. 2011; Rocha-Filho et al. 2013). For this reason, it was suggested that dispersal differences between both sexes is a matter that should be better investigated by comparing genetic differentiation among Euglossini populations based on both nuclear and mitochondrial genomes (Cerântola et al. 2011).

Thus, in our study, differences in the genetic structure of E. iopoecila populations revealed by mtDNA and microsatellite markers could be related to the maternal origin of mtDNA (Avise 2004) and therefore to acknowledged female philopatry 
(see Cerântola et al. 2011). In addition, the intrinsic characteristics of mtDNA, including its better conserved character, lack of recombination and lower mutation rate per mtDNA locus compared with microsatellite markers (Avise 2004), should also be treated as further possible causes for the discrepancies in the levels of differentiation detected by these markers.

The pattern of isolation by distance exhibited by E. iopoecila differs from that found for most euglossine species studied so far (Freiria et al. 2012; Rocha-Filho et al. 2013; Boff et al. 2014; Suni et al. 2014). Only Zimmermann et al. (2011) and Suni and Brosi (2011), in their respective studies of Euglossa dilemma populations in Mexico and E. bombiformis in Costa Rica, detected a significant positive correlation between genetic distance and geographical distance for these species. Based on their findings, Suni and Brosi (2011) suggest that the mobility of orchid bees differs significantly among species. Considering our results, the pattern of isolation by distance exhibited by E. iopoecila also suggests that this orchid bee species shows limited dispersal ability when compared with other euglossine species. Despite this, the estimates of $F_{\mathrm{ST}}$ and $D_{\text {est }}$ for E. iopoecila revealed by microsatellite markers did not differ conspicuously from those reported for populations of other euglossine species (Zimmermann et al. 2011; Freiria et al. 2012; Rocha-Filho et al. 2013; Boff et al. 2014; Suni et al. 2014). These authors also used microsatellite markers to assess the population structure of different euglossine species and detected either a lack of genetic differentiation in the populations or levels of differentiation ranging from low to moderate.

In our study, it was interesting to note that the various analyses of data on E. iopoecila populations at Ilhabela (IB) and São Sebastião (SS) revealed either no genetic differentiation or a low level of differentiation among these populations. In this case, it appears that the distance of $2 \mathrm{~km}$ between the island and the mainland is not a barrier to gene flow between the populations at these two locations. This finding is supported by the literature, which includes several reports that euglossine bees are able to cross water bodies (e.g. Boff et al. 2014). Taking into account the known flight ability of euglossine bees (Janzen 1971) as well as the dispersal ability of these male bees and the correlation between geographical distance and genetic distance, the stepping stone model (Kimura and Weiss 1964) appears to be the model that best explains the results revealed by the nuclear markers for E. iopoecila populations.

Regarding the conservation measures for populations of E. iopoecila surveyed across the $\mathrm{SMBC}$, the incongruence between the patterns of genetic structure revealed by mitochondrial and nuclear markers has also important implications. According to Frankham et al. (2010), appropriate management and conservation measures for highly structured populations are different from those required for populations showing no structure at all or low-to-intermediate levels of structure. Thus, if we had to make decisions aiming a better conservation of the E. iopoecila populations studied based only on microsatellite data, it is probable that the management measures to be implemented would not be the most suitable for conserving the genetic diversity of such populations. Both AMOVA and Bayesian results for the mtDNA data support this statement. In particular, the two distinctive units identified by BAPS strongly indicate the occurrence of two ESUs among the six populations of E. iopoecila studied. Furthermore, the haplotype differences found between the samples from União Reserve (from Rio de Janeiro State) and the locations sampled further south in the SMBC also point to two ESUs.

Another striking result that merits further study is the fact that Ubatuba was the only region to share haplotypes with the samples of E. iopoecila collected in the states of Paraná (Salto Morato and Superagui Island) and São Paulo (São Sebastião and Ilhabela Island), as well as the state of Rio de Janeiro (União Reserve). It is also important to note that the Ubatuba population showed the lowest estimates of private allelic richness. Curiously, in the same region (Ubatuba), Ferrari and Melo (2014) found a male E. iopoecila showing a mixture of blue and green integument. Thus, besides corroborating the results of Ferrari and Melo 
(2014), our results point to the region of Ubatuba as a possible hybrid zone of E. iopoecila populations that most likely serves as a connection and a mixing zone between the genotypes of the two main ESUs detected in our study. This has important implications for Euglossini populations occurring along the SMBC. Hybridisation zones are regions where genetically distinct populations meet, mate and produce offspring of mixed ancestry (Harrison 1993).

Investigating the impact of Pleistocene climate change on three Neotropical orchid bee species, López-Uribe et al. (2014) concluded that climatic instability, such as that resulting from events of large-scale climatic changes, is an important mechanism of maternal lineage diversification in orchid bees. In our study, the two distinctive lineages revealed by the mtDNA markers of E. iopoecila populations across the Serra do Mar Biodiversity Corridor (SMBC) could thus be related to historical climate changes that occurred throughout the Quaternary. This hypothesis finds support in studies indicating that during the Quaternary, between 21,000 and 12,000 years before present, a forestsavannah vegetation mosaic was established and that this type of formation reached the east coast of Brazil and was replaced by RF vegetation in more recent times. Between the States of São Paulo and Rio de Janeiro, savannah areas extended to the coast (Oliveira et al. 2005), while RF domains were present on the Brazilian coast, extending over the coastal areas of the states of Santa Catarina, Paraná and São Paulo. Such areas are currently endemic areas for different groups of animals (DaSilva and Pinto-da-Rocha 2011).

Therefore, the two different lineages revealed by mtDNA markers could be reflecting a temporary interruption in the gene flow between populations of E. iopoecila from Rio de Janeiro and the regions further south. This argument relies on the fact that the E. iopoecila population sampled at União Reserve (Rio de Janeiro State) shared haplotypes only with the population sampled at Ubatuba. Even so, only three haplotypes were shared by these two populations, which were present at a lower frequency in the E. iopoecila population of Ubatuba. In contrast, the $\mathrm{H} 1$ haplotype, which was more frequent in the populations from the states of São Paulo and Paraná, did not occur in the Rio de Janeiro population. Interestingly, Faria Jr. and Melo (2007) and Ferrari and Melo (2014) reported that an analysis of the integument colour variation in populations of this species showed that blue-violet colouration is found further south (Santa Catarina and Paraná States), while a green integument is observed in populations further north (States of Espírito Santo and Bahia). Although these authors used mtDNA markers as a tool to help resolve taxonomic problems involving E. iopoecila populations across the SMBC, their findings are similar to ours. Finally, the haplotype network identified appears to reflect precisely how the E. iopoecila populations in the SMBC are structured. In other words, there is clear differentiation between the haplotypes found in the Rio de Janeiro population, which showed only a few haplotypes shared with Ubatuba (UB), while there was an absence of the most frequent haplotype (H1) found in other populations in the Rio de Janeiro population.

The differences revealed by the analysis of the 651-bp segment of the Cytb gene among the six E. iopoecila populations sampled along a $700 \mathrm{~km}$ stretch of coastline extending over three Brazilian states indicate that this mtDNA region is very informative for making possible biogeographic and evolutionary inferences concerning this Euglossini species. As demonstrated by López-Uribe et al. (2014), mtDNA is a very informative marker for population studies involving euglossine bees.

Overall, our findings suggest that, for conservation purposes, the populations of E. iopoecila from the northern and southern limits of this Atlantic Forest area should be considered distinctive ESUs. Also, the results presented in this study provide a new perspective for genetic studies on Euglossini populations aimed at conserving these bees, indicating that greater attention should be paid to the analysis of mtDNA markers to achieve a more accurate idea of how such bee populations are actually structured. 


\section{ACKNOWLEDGEMENTS}

The authors thank CNPq, CAPES/Procad (158/ 2007), Fundação Araucária and FBPN for financial support; CAPES for a scholarship awarded to R.E.S. Penha; Maria C. Arias and Elaine Françoso (USP) for the valuable support in constructing the microsatelliteenriched library; ICMBio and IAP, Salto Morato Reserve and IF-São Paulo for the collecting permits; the staff of the State Parks of São Sebastião, Ilhabela and UB (Picinguaba) and the Salto Morato Reserve for providing infrastructure and for their assistance during sampling. Silvia H. Sofia and Maria C. Gaglianone are research fellows from CNPq. Finally, the authors would like to thank the two anonymous reviewers for their valuable comments and suggestions.

L'ADN mitochondrial d' Euglossa iopoecila (Apidae, Euglossini) révèle deux lignées distinctes pour cette espèce d'abeille à orchidée endémique de la Forêt Atlantique

euglossine / diversité génétique / marqueur microsatellite / ADNmt / unité évolutive significative

Die Analyse mitochondrialer DNA von Euglossa iopoecila (Apidae, Euglossini) gibt Hinweise auf das Vorkommen zweier unterschiedlicher genetischer Linien dieser im Atlantischen Regenwald endemischen Prachtbiene

Euglossinen / genetische Diversität / Mikrosatellitenmarker / mtDNA / evolutiv signifikante Einheiten

\section{REFERENCES}

Archie, J.W. (1985) Statistical analysis of heterozygosity data: independent sample comparisons. Evolution 39, 623-637

Augusto, S.C., Garófalo, C.A. (2004). Nesting biology and social structure of Euglossa (Euglossa) townsendi Cockerell (Hymenoptera, Apidae, Euglossini). Insect. Soc. 51, 400-409

Avise, J.C. (2004). Molecular Markers, Natural History and Evolution. 2nd edn., Sinauer: Sunderland

Bandelt, H.-J., Forster, P., Röhl, A. (1999). Median-joining networks for inferring intraspecific phylogenies. Mol. Biol. Evol. 16, 37-48

Bawa, K.S., Seidler, R .(1998). Natural forest management and conservation of biodiversity in tropical forests. Conserv. Biol 12, 46-55
Billotte, N., Lagoda, P., Risterucci, A.M., Baurens, F.-C. (1999). Microsatellite-enriched libraries: applied methodology for the development of SSR markers in tropical crops. Fruits 54, 277-288

Boff, S., Soro, A., Paxton, R.J., Alves-dos-Santos, I. (2014). Island isolation reduces genetic diversity and connectivity but does not significantly elevate diploid male production in a neotropical orchid bee. Conserv. Genet. doi:10.1007/s10592-014-0605-0

Brown, M.J.F., Paxton, R.J. (2009). The conservation of bees: a global perspective. Apidologie 40, 410-416

Cerântola, N.C.M., Oi, C.A., Cervini, M., Del Lama, M.A. (2011). Genetic differentiation of urban populations of Euglossa cordata from the state of São Paulo, Brazil. Apidologie 42, 214-222

Corander, J., Marttinen, P., Siren, J., Tang, J. (2008). Enhanced Bayesian modelling in BAPS software for learning genetic structures of populations. BMC Bioinform. 9, 539

DaSilva, M.B., Pinto-da-Rocha, R. (2011). História biogeográfica da Mata Atlântica: opiliões (Arachnida) como modelo para sua inferência. In: Carvalho, C.J.B., Almeida, E.A.B... (eds.), Biogeografia da América do Sul-Padrões e Processos. Editora Roca: São Paulo. pp. 221-238

Excoffier, L., Lischer, H.E.L. (2010). Arlequin suite v. 3.5: a new series of programs to perform population genetics analyses under Linux and Windows. Mol. Ecol. Resour. 10, 564-567

Excoffier, L., Smouse, P.E., Quattro, J.M. (1992). Analysis of molecular variance inferred from metric distances among DNA haplotypes: application to human mitochondrial DNA restriction data. Genetics 131, 479491

Faria Jr., L.R.R., Melo, G.A.R. (2007). Species of Euglossa (Glossura) in the Brazilian Atlantic forest, with taxonomic notes on Euglossa stellfeldi Moure (Hymenoptera, Apidae, Euglossina). Rev. Bras. Entomol. 51, 275-284

Ferrari, B.R., Melo, G.A.R. (2014) Deceiving colors: recognition of color morphs as separatespecies in orchid bees is not supported by molecular evidence. Apidologie doi:10.1007/s13592-014-0280-7

Frankham, R., Ballou, J.D., Briscoe, D.A. (2010). Introduction to Conservation Genetics, 2nd edn. Cambridge University Press: Cambridge

Freiria, G.A., Ruim, J.B., Souza, R.F., Sofia, S.H. (2012). Population structure and genetic diversity of the orchid bee Eufriesea violacea (Hymenoptera, Apidae, Euglossini) from Atlantic Forest remnants in southern and southeastern Brazil. Apidologie 43, 392-402

Freitas B.M., Imperatriz-Fonseca V.L., Medina L.M., Kleinert A.M.P., Galetto L., Nates-Parra G., Quezada-Euán J.J.G. (2009). Diversity, threats and conservation of native bees in the Neotropics, Apidologie 40, 332-346

Galindo-Leal, C., Câmara, I.G. (2003). Atlantic Forest hotspot status: an overview. In: Galindo-Leal, C., 
Câmara, I.G. (eds.), The Atlantic Forest of South America: Biodiversity Status, Threats, and Outlook. Center for Applied Biodiversity Science and Island Press: Washington DC. pp. 3-11

Giangarelli, D.C., Freiria, G.A., Collatreli, O.P., Suzuki, K.M., Sofia, S.H. (2009). Eufriesea violacea (Blanchard) (Hymenoptera: Apidae): an orchid bee apparently sensitive to size reduction in forest patches. Neotrop. Entomol. 38, 610-615

Hall, T.A. (1999). BioEdit: a user-friendly biological sequence alignment editor and analysis program for Windows 95/98/NT. Nucl. Acids Symp. Ser. 41, 95-98

Harrison, R.G. (1993). Hybrid Zones and the Evolutionary Process. Oxford University Press: New York.

Janzen, D.H. (1971). Euglossine bees as long-distance pollinators of tropical plants. Science 171, 203-205

Jost, L. (2008). G $\mathrm{ST}_{\mathrm{ST}}$ and its relatives do not measure differentiation. Mol. Ecol. 17, 4015-4026

Kalinowski, S.T. (2005). Hp-rare 1.0: a computer program for performing rarefaction on rarefaction on measures of allelic richness. Mol. Ecol. Notes 5, 187-189

Kimura, M., Weiss, G.H. (1964). The stepping stone model of population structure and the decrease of genetic correlation with distance. Genetics 49, 561-576

Librado, P., Rozas, J. (2009). DnaSP v5: a software for comprehensive analysis of DNA polymorphism data. Bioinformatics 25, 1451-1452

López-Uribe, M.M., Zamudio, K.R., Cardoso, C.F., Danforth, B.N. (2014). Climate, physiological tolerance and sex-biased dispersal shape genetic structure of Neotropical orchid bees. Mol. Ecol. doi:10.1111/ mec. 12689

Moritz, C. (1999). Conservation units and translocations: strategies for conserving evolutionary processes. Hereditas 130, 217-228

Nemésio, A. (2009). Orchid bees (Hymenoptera: Apidae) of the Brazilian Atlantic forest. Zootaxa 2041, 1-242

Nemésio, A. (2011). Euglossa marianae sp. n. (Hymenoptera: Apidae): a new orchid bee from the Brazilian Atlantic forest and the possible first documented local extinction of a forest-dependent orchid bee. Zootaxa 2892, 59-68

Oliveira, P.E., Behling, H., Ledru, M.-P., Barberi, M., Bush, M. (2005). Paleovegetação e paleoclimas do Quartenário do Brasil. In: Souza, C.R.G., Suguio, K., Santos, A.M., Oliveira, P.E. (eds.), Quaternário do Brasil. Editora Holos: Ribeirão Preto. pp. 52-74

Paxton, R.J., Zobel, M.U., Steiner, J., Zillikens, A. (2009). Microsatellite loci for Euglossa annectans (Hymenoptera: Apidae) and their variability in other orchid bees. Mol. Ecol. Resour. 9, 1221-1223

Peakall, R., Smouse, P.E. (2012). GenAlEx 6.5: genetic analysis in Excel. Population genetic software for teaching and research an update. Bioinformatics 28, 2537-2539
Ramalho, A.V., Gaglianone, M.C., Oliveira, M.L. (2009). Comunidades de abelhas Euglossina (Hymenoptera, Apidae) em fragmentos de Mata Atlântica no Sudeste do Brasil. Rev. Bras. Entomol. 53, 95-101

Raymond, M., Rousset, F. (1995). GENEPOP (version 1.2): population genetics software for exact tests and ecumenicism. J. Heredity 86, 248-249

Rocha-Filho, L.C., Cerântola, N.C.M., Garófalo, C.A., Imperatriz-Fonseca, V.L., Del Lama, M.A. (2013). Genetic differentiation of the Euglossini (Hymenoptera, Apidae) populations on a mainland coastal plain and an island in southeastern Brazil. Genetica 141, 65-74

Rousset, F. (2008). Genepop'007: a complete reimplementation of the Genepop software for Windows and Linux. Mol. Ecol. Resources 8, 103106

Rozen, S., Skaletsky, H.J. (2000). Primer3 on the WWW for general users and for biologist programmers In: Krawetz, S., Misener, S. (eds.), Bioinformatics Methods and Protocols: Methods in Molecular Biology. Humana Press: Totowa. pp. 361-386

Schuelke, M. (2000). An economic method for the fluorescent labeling of PCR fragments: a poor man's approach to genotyping for research and high-throughput diagnostics. Nature Biotechnol. 18, 232-234

Simon, C., Frati, F., Beckenbach, A., Crespi, B., Liu, H., Flook, P. (1994). Evolution, weighting, and phylogenetic utility of mitochondrial gene sequences and a compilation of conserved polymerase chain reaction primers. Ann. Entomol. Soc. Am. 87, 652-701

Souza, R.O., Cervini, M., Del Lama, M.A., Paxton, R.J. (2007). Microsatellite loci for euglossine bees (Hymenoptera: Apidae). Mol. Ecol. Resour. 7, 13521356

Suni, S.S., Brosi, B.J. (2011). Population genetics of orchid bees in a fragmented tropical landscape. Conserv. Genet. 13, 323-332

Suni, S.S., Bronstein, J.L., Brosi, B.J. (2014). Spatiotemporal genetic structure of a tropical bee species suggests high dispersal over a fragmented landscape. Biotropica 46, 202-209

Vallone, P.M., Butler, J.M. (2004). AutoDimer: a screening tool for primer-dimer and hairpin structures. BioTechniques 37, 226-31

Wang, I.J. (2010). Recognizing the temporal distinctions between landscape genetics and phylogeography. Mol. Ecol. 19, 2605-2608

Wright, S. (1978). Evolution and genetics of populations. Vol. 4. Variation within and among natural populations. University of Chicago Press, Chicago

Zimmermann, Y., Schorkopf, D.L.P., Moritz, R.F., Pemberton, R.W., Quezada-Euán, J.J.G., Eltz, T. (2011). Population genetic structure of orchid bees (Euglossini) in anthropogenically altered landscapes. Conserv. Genet 12, 1183-1194 